\title{
An undescribed species of velvet worm from Chiapas, Mexico (Onychophora: Peripatidae)
}

\author{
Xocoyotzin Toledo-Matus', Gustavo Rivera-Velázquez ${ }^{1,2}$, Julián Monge-Nájera ${ }^{3}$ \& Bernal Morera-Brenes ${ }^{4}$ \\ 1. Instituto de Ciencias Biológicas, Universidad de Ciencias y Artes de Chiapas, Apartado postal 57, C.P.29000, Tuxtla Gutiérrez, Chiapas, México; \\ xoco_yotzin95@hotmail.com \\ 2. Laboratorio de Acuacultura y Evaluación Pesquera, Universidad de Ciencias y Artes de Chiapas, A.P. 57, C.P.29000, Tuxtla Gutiérrez, Chiapas, \\ México; gustavo.rivera@unicach.mx \\ 3. Laboratorio de Ecología Urbana, Universidad Estatal a Distancia, 2050 San José, Costa Rica; julianmonge@gmail.com \\ 4. Laboratorio de Genética Evolutiva, Escuela de Ciencias Biológicas, Universidad Nacional, Heredia, Costa Rica; bernal.morera@gmail.com
}

Received 05-IX-2017 • Corrected 23-X-2017 • Accepted 16-XI-2017

\begin{abstract}
Onychophoran worms are considered "living fossils" because their basic body structure has changed little in 500 million years. Only two species have been properly recorded from Mexico: Macroperipatus perrieri from Veracruz, and Oroperipatus eisenii from Nayarit. Here we report an undescribed species of Oroperipatus from Tuxtla Gutiérrez, Chiapas. Males, which are rarer, smaller and reddish than females, are $3-4 \mathrm{~cm}$ long and have $24-25$ leg pairs $(\mathrm{N}=6)$. Females are $4-7,5 \mathrm{~cm}$ long and have $28-29$ pairs $(\mathrm{N}=19)$. We propose the common name "Tuxtla Brownish Purple Velvet Worm" to help study and protect the species until it receives formal description. This new record expands the known distribution of the phylum in Mexico from the evergreen forest of Veracruz to the deciduous forest of Tuxtla $(400 \mathrm{Km})$.
\end{abstract}

Key words: extension of geographic range, new locality, new undescribed species, velvet worm, urban onychophorans.

Velvet worms (phylum Onychophora) are considered "living fossils" because their morphology has changed little for 500 million years (Monge-Nájera \& Hou, 1999). They are small terrestrial invertebrates that live in humid dark places, mainly under leaf litter and rocks, or inside micro-caverns, rotten trunks and bromeliads (MongeNájera, 1994; Morera-Brenes, 2012).

The phylum has around 200 described species, geographically distributed in the continental plates that once formed Pangea (Oliveira, Read \& Mayer, 2012). There are two families, Peripatopsidae, in the southern
RESUMEN: Una especie no descrita de gusano de terciopelo de Chiapas, México (Onychophora: Peripatidae). Los gusanos onicóforos son considerados "fósiles vivientes" porque su estructura corporal ha cambiado poco en 500 millones de años. En México solamente se han confirmado Macroperipatus perrieri de Veracruz, y Oroperipatus eisenii de Nayarit. Aquí reportamos una especie no descrita de Oroperipatus de Tuxtla Gutiérrez, Chiapas. Los machos, que son más escasos, pequeños y rojizos que las hembras, miden $3-4 \mathrm{~cm}$ de largo y tienen $24-25$ pares de patas $(\mathrm{N}=6)$. Las hembras miden $4-7,5 \mathrm{~cm}$ de largo y tienen 28-29 pares $(\mathrm{N}=19)$. Proponemos el nombre común "onicóforo morado parduzco de Tuxtla" para ayudar a estudiar y proteger a la especie hasta que reciba una descripción formal. Este nuevo registro amplía la distribución conocida del filo en México del bosque perenne de Veracruz al bosque caducifolio de Tuxtla (400Km).

Palabras clave: extensión del ámbito geográfico, nueva localidad, nuevas especies no descritas, gusano de terciopelo, onicóforos urbanos. hemisphere; and Peripatidae, in the equatorial region. They are characterized by the solubility (Peripatidae) or insolubility (Peripatopsidae) of body pigments in ethanol and by a few general morphological traits (Jerez-Jaimes \& Bernal-Pérez, 2009).

Threespeciesare reported from Mexico:Macroperipatus perrieri (Bouvier) from Veracruz, Oroperipatus eisenii (Wheeler) from Nayarit, and Oroperipatus goudoti (Bouvier) from an unknown location (Wheeler, 1898; Bouvier, 1905; Cupul-Magaña \& Navarrete-Heredia, 2008). However, O. goudoti is among nomina dubia for its 
imprecise type locality (Oliveira et al., 2012). There are also DNA sequences from two unidentified Mexican species: DNA103556 in GenBanK ${ }^{\circledR}$ (Murienne, Daniels, Buckley, Mayer \& Giribet, 2014), and CTM202-13, CTM204-13, CTM205-13, CTM206-13 in Barcode of Life Data Systems (BOLD Systems, 2014).

To our knowledge, this is the first record of onychophorans from Chiapas.

From July, 2015, through October, 2017, a total of 29 onychophorans were found in the campus of Universidad de Ciencias y Artes de Chiapas, UNICACH, located in Tuxtla Gutiérrez, Chiapas, Mexico (16 $46^{\prime} 33^{\prime \prime}$ $\left.\mathrm{N}-93^{\circ} 07^{\prime} 21^{\prime \prime} \mathrm{W}\right)$. On July $18^{\text {th }}, 2015$, individuals shown in Digital Figure 1 were collected, anesthetized with ether, sacrificed in alcohol, and fixed with $10 \%$ formaldehyde for 24 to 48 hours. They are stored in $70 \%$ alcohol and deposited in the Colección de Macroinvertebrados del Laboratorio de Acuacultura y Evaluación Pesquera (LAyEP), Instituto de Ciencias Biológicas (ICB), UNICACH (MZ-MI-O-0001 y 0002).

We identified them as Oroperipatus sp. for the two pedal papillae on each side, but they did not match characters for the geographically closest species, Oroperipatus eisenii (according to the key in Peck, 1975). Males, which are rarer, smaller and reddish than females, are $3-4 \mathrm{~cm}$ long and have $24-25$ leg pairs $(\mathrm{N}=6)$. Females are $4-7,5 \mathrm{~cm}$ long and have $28-29$ pairs $(\mathrm{N}=19)$. All length measurements are from live animals.

They occur in vertisol ground covered with grassland and small trees (up to $10 \mathrm{~m}$ high), mostly Prunus virginiana, Pseudobombax ellipticum, and Leucaena leucocephala. The original vegetation in the area was low deciduous forest (Breedlove, 1981). The worms were found by turning over small rocks during the rainy season; apparently they spend dry periods deeper in the ground, in micro-caverns made by earthworms and other organisms.

This new species and record expand the known distribution of onychophorans in Mexico, ecologically from the evergreen forest of Veracruz to the deciduous forest of Tuxtla Gutiérrez, and geographically by $400 \mathrm{Km}$ (Digital Figure 2).

In Mexico, there may be at least 14 species (MongeNájera, 2000) suggesting that the vast majority remain unrecognized. Common names allow the aggregation of data for conservation of undescribed species (SosaBartuano, Monge-Nájera, \& Morera-Brenes, 2018). We propose the common name "Tuxtla Brownish Purple Velvet Worm" for this species, so that it can be studied and protected with it until it receives formal description.

We thank three anonymous reviewers for useful comments.

\section{REFERENCES}

BOLD Systems. (2014). International barcode of life. Retrieved from www.boldsystems.org

Bouvier, E. L. (1905). Monographie des Onychophores. I. Annales des Sciences Naturelles - Zoologie et Biologie Animale Ser., 9(2), 1-383.

Breedlove, D. E. (1981). Introduction to the Flora of Chiapas. Part 1. San Francisco, California: California Academy of Sciences.

Cupul-Magaña, F. G., \& Navarrete-Heredia, J. L. (2008). Rediscovery and new data for Oroperipatus eisenii (Wheeler, 1898) from Mexico (Onychophora: Peripatidae). Entomological News, 119, 545-549. doi:10.3157/0013-872X-119.5.545

Jerez-Jaimes, J. H., \& Bernal-Pérez,M. C.(2009). Taxonomía de onicóforos de Santander, Colombia y termogravimetría, calorimetría de barrido diferencial y espectroscopía infrarroja de la secreción adhesiva (Onychophora: Peripatidae). Revista de Biología Tropical, 57(3), 567-588.

Monge-Nájera, J. (1994). Ecological Biogeography in the Phylum Onychophora. Biogeographica, 70, 111-123.

Monge-Nájera, J. (2000). Onychophora. In Biodiversidad, taxonomía y biogeografía de artrópodos de México: hacia una síntesis de su conocimiento, vol. II. (pp. 105-114). J. Llorente, E. González, A. García, \& N. Papavero (eds.). México, D.F.: Universidad Nacional Autónoma de México.

Monge-Nájera. J., \&Hou, X. (1999). 500 millones de años de evolución: Onicóforos, los primeros animales que caminaron (Onychophora). Sociedad Entomológica Aragonesa (España), 26, 171-176.

Morera-Brenes, B. (2012). Los onicóforos, fósiles caminantes. El Salvador Ciencia \& Tecnología, 7 (23), 08-13.

Murienne, J., Daniels, S. R., Buckley, T. R., Mayer, G., \& Giribet, G. (2014). A living fossil tale of Pangaean biogeography. Proceedings of the Royal Society B, 281, 20132648. doi:10.1098/rspb.2013.2648

Oliveira, I. S., Read V. M. S. J., \& Mayer, G. (2012). A world checklist of Onychophora (velvet worms), with notes on nomenclature and status of names. ZooKeys, 211, 1-70. doi:10.3897/zookeys.211.3463

Peck, S.B. (1975). A review of the new world Onychophora with the description of a new cavernicolous genus and species from Jamaica. Psyche, 8, 341-358. doi:10.1155/1975/98614

Sosa-Bartuano, A., Monge-Nájera, J., \& Morera-Brenes, B. (2018). A proposed solution to the species problem in velvet worm conservation (Onychophora). UNED Research Journal, 10(1), 193-197.

Wheeler, W. M. (1898). A new Peripatus from Mexico. Journal of Morphology, 15, 1-8.

See Digital Appendix at: / Ver Apéndice digital en: http://investiga.uned.ac.cr/revistas/index.php/cuadernos 